\title{
Prometheus therapy for the treatment of acute liver failure in patients after cardiac surgery
}

\author{
Ekaterina Komardina, Michael Yaroustovsky, Marina Abramyan, Marina Plyushch \\ Department of Blood Purification "A.N. Bakulev National Medical Research Center for Cardiovascular Surgery" \\ of the Ministry of Health of Russian Federation, Moscow, Russia
}

Kardiochirurgia i Torakochirurgia Polska 2017; 14 (4): 230-235

\begin{abstract}
Introduction: Acute liver failure usually develops in multiple organ dysfunction syndrome and significantly increases the mortality risk in patients after cardiac surgery.

Aim: To assess the safety and efficacy of extracorporeal liver support in patients with acute liver failure after cardiac surgery. Material and methods: We studied 39 adult patients with multiple organ dysfunction syndrome and acute liver failure as postoperative complication, treated with Prometheus therapy. Inclusion criteria comprised clinical and laboratory signs of acute liver failure. Criteria to start Prometheus therapies were: serum bilirubin above $180 \mu \mathrm{mol} / \mathrm{l}$ (reference values: 3-17 $\mu \mathrm{mol} / \mathrm{l}$ ), hepatocyte cytolysis syndrome (at least 2-fold increase in aspartate aminotranspherase and alanine aminotranspherase concentrations; reference values 10-40 U/I) and decrease in plasma cholinesterase (reference values 4490-13 $320 \mathrm{U} / \mathrm{l}$ ). Results: Extracorporeal therapy provided stabilization of hemodynamics, decrease in serum total bilirubin and unconjugated bilirubin levels, decrease in cytolysis syndrome severity and positive effect on the synthetic function of the liver. The 28-day survival rate in the group treated with Prometheus therapy was $23 \%$.

Conclusions: Prometheus procedures could be recommended as a part of combined intensive care in patients with acute liver failure after cardiac and major vessel surgery. The efficiency of this method could be improved by a multi-factor evaluation of patient condition in order to determine indications for its use.
\end{abstract}

Key words: acute liver failure, bilirubin, Prometheus, cardiac surgery.

\section{Introduction}

Acute liver failure (ALF) usually develops in multiple organ dysfunction syndrome (MODS) after cardiac surgery. The rate of developing MODS after cardiac surgery with cardiopulmonary bypass (CPB) is relatively low (4.7\%), but

\section{Streszczenie}

Wstęp: Do rozwoju ostrej niewydolności wątroby dochodzi zwykle w zespole niewydolności wielonarządowej. Zwiększa ona istotnie ryzyko zgonu u pacjentów po zabiegach kardiochirurgicznych.

Cel: Ocena bezpieczeństwa i skuteczności pozaustrojowego wspomagania czynności wątroby u pacjentów z ostrą niewydolnością wątroby po zabiegach kardiochirurgicznych.

Materiał i metody: Zbadano 39 dorosłych pacjentów z powikłaniami pooperacyjnymi w postaci zespołu niewydolności wielonarządowej i ostrej niewydolności wątroby, których leczono za pomocą systemu Prometheus. Kryteria włączenia obejmowały kliniczne i laboratoryjne oznaki ostrej niewydolności wątroby. Stosowane kryteria rozpoczęcia terapii Prometheus to: stężenie bilirubiny w surowicy powyżej $180 \mu \mathrm{mol} / \mathrm{l}$ (wartości referencyjne: 3-17 $\mu \mathrm{mol} / \mathrm{l}$ ), zespół cytolizy hepatocytów (przynajmniej dwukrotny wzrost stężeń aminotransferazy asparaginianowej i alaninowej; wartości referencyjne: 10-40 U/I) oraz zmniejszenie stężenia cholinesterazy w osoczu (wartości referencyjne: 4490-13 320 U/l).

Wyniki: Leczenie pozaustrojowe spowodowało stabilizację hemodynamiczną, zmniejszenie całkowitego stężenia sprzężonej i niesprzężonej bilirubiny w surowicy, zmniejszenie nasilenia zespoły cytolizy oraz poprawę syntetycznej funkcji wątroby. Wskaźnik 28-dniowych przeżyć u pacjentów leczonych systemem Prometheus wyniósł 23\%.

Wnioski: Zastosowanie systemu Prometheus można zalecać w ramach intensywnej terapii pacjentów z ostrą niewydolnością wątroby po operacjach na sercu i dużych naczyniach. Skuteczność tej metody można zwiększyć, dokonując wieloczynnikowej oceny stanu pacjentów, aby ustalić wskazania do jej użycia.

Słowa kluczowe: ostra niewydolność wątroby, bilirubina, Prometheus, kardiochirurgia.

its mortality rate is $61.2 \%$ [1], while its combination with ALF increases the mortality rate up to $90 \%$ [2]. Despite the progress of conservative therapy methods for ALF, extracorporeal blood purification methods play an important role at present in the combined intensive care [3, 4].

Address for correspondence: Ekaterina Komardina, Department of Blood Purification "A.N. Bakulev National Medical Research Center for Cardiovascular Surgery" of the Ministry of Health of Russian Federation, Rublevskoe Highway 135, 121552 Moscow, Russia, phone: +7 903 7308187, e-mail: nesluchainost@mail.ru

Received: 3.08.2017, accepted: 14.09.2017. 
The effectiveness of these methods for the treatment of ALF is based on their ability to remove albumin bound hydrophobic and water-soluble substances from the blood, allowing reduction of hepatocyte injury and providing the time to recover organ functions or to perform liver transplantation. One of the goals of extracorporeal therapy in ALF is the increase of albumin binding capacity by removing the albumin bound substances.

Currently, there are two groups of extracorporeal methods to support liver functions: systems containing cells (human or animal hepatocytes), and techniques without biological substrates.

Extracorporeal methods based on a patient's blood perfusion through exogenous hepatocytes have not been widely used due to their high complexity and cost, the insufficient cell mass for liver regeneration ( $\geq 400 \mathrm{~g}$ would be needed) as well as low biocompatibility and infection risk.

Modern extracorporeal blood purification methods without using biological components comprise high-volume plasma exchange, albumin dialysis (Molecular Adsorbent Recirculating System (MARS), single-pass albumin dialysis (SPAD)) and methods that combine plasma separation and adsorption (Fractionated Plasma Separation and Adsorption (FPSA) Prometheus).

Plasma exchange in ALF reduces hyperbilirubinemia, but this is achieved only with high volume exchange (up to $10 \mathrm{l}$ ), while the lack of specificity and a high risk of allergic reactions or infections decrease the advantages of this method [5].

Single-pass albumin dialysis therapy uses standard equipment for kidney replacement therapy with a highly porous dialyser and albumin containing dialysis solutions to remove hydrophobic substances.

Molecular Adsorbent Recirculating System therapy uses a filter that allows molecules up to a size of $50 \mathrm{kDa}$ to cross the membrane. Toxins transitionally accumulated at the filter membrane are bound by albumin used in the dialysis fluid. The albumin solution, in turn, comes to a low permeable dialyzer where it is regenerated from water soluble compounds. Successive passage through the two absorbers containing activated carbon and ion exchange resin provides removal of hydrophobic molecules bound by albumin followed by the recirculation of purified albumin solution as a dialysis fluid. MARS therapy and SPAD provide similar clearance of water soluble and hydrophobic substances [6].

The Prometheus system uses the principle of plasma separation in a filter permeable for albumin, clotting factors and fibrinogen, and regeneration of patient plasma by successive passage through the absorbers containing ion exchange and neutral resins. The water-soluble low molecular compounds are removed by passing the patient's blood through a hemodialyzer. This is the most effective procedure to eliminate unconjugated bilirubin and bile acids [7].

\section{Aim}

There are only a few multi-center, prospective studies using these therapies in ALF, and only a small number of domestic studies of ALF treatment after cardiac surgery.
The purpose of this report is to analyze the effectiveness of one extracorporeal liver support system (Prometheus) in patients with ALF after cardiac and vascular surgery.

\section{Material and methods}

For this report the results of combined intensive care including Prometheus procedures obtained during 2010-2016 in the Intensive Care Unit of Bakoulev Center for Cardiovascular Surgery were analyzed. So this is a retrospective data review of uncontrolled clinical data. The rate of developing ALF after cardiac surgery with cardiopulmonary bypass (CPB) in our center for the period 2010-2016 was 0.25\%; that is why we treated all the patients with ALF and did not form a control group. The study was approved by the local ethics committee of the A.N. Bakoulev NSPCCS.

So, the analyzed group comprised 39 patients, whose post-operational period was complicated by the development of MODS in combination with ALF and who received Prometheus therapy. The average age of patients was 59 (52-65), and there were 19 males. All patients underwent surgery due to their congenital or acquired cardiac and major vessel pathology (Tab. I). The duration of CPB was 237 (179-325) min, aortic cross clamp time was 132 (91-190) min.

At the early post-operation stages (1-5 day), all patients developed low cardiac output syndrome: on treatment with high doses of combined cardiotonic therapy, and, in some cases, intra-aortic balloon pump therapy, average left ventricle output fraction (measured by transthoracic echocardiogram) was 38\%.

Acute liver failure was observed, on average, by day 10 . At that time, dosages of cardiotonic drugs were reduced to therapeutic levels (adrenaline: $0.06(0.04-0.1) \mu \mathrm{g} / \mathrm{kg} / \mathrm{min}$, noradrenaline: $0.07(0.05-0.2) \mu \mathrm{g} / \mathrm{kg} / \mathrm{min}$, dobutamine: 8 (5-8), dopamine: 5 (4-7) $\mu \mathrm{g} / \mathrm{kg} / \mathrm{min})$; low cardiac output syndrome remained in $38 \%(n=15)$ of cases.

Central venous pressure (CVP) was maintained at 9-10 mm Hg.

All patients had breathlessness, which required respiratory support. The oxygenation index prior to extracorporeal liver support was 2.25 (1.77-3).

At baseline, in our group 9 patients were conscious (15), 7 were moderately conscious (13-14), 9 were deeply unconscious (11-12), 8 were in a semi-coma (10), 5 in a moderate coma (8-9) and one in a deep coma (5).

Tab. I. Cardiac surgery pathology structure

\begin{tabular}{lc} 
Cardiac surgery pathology type & $\begin{array}{c}\text { Prometheus } \\
(n=39)(\%)\end{array}$ \\
\hline Acquired heart valvular disease & 59 \\
\hline Congenital heart valvular disease & 5 \\
\hline Ischemic heart disease & 18 \\
\hline Aortic dissection & 8 \\
\hline Infective endocarditis & 10 \\
\hline
\end{tabular}


The APACHE II score was 25 (20-30). The MELD score prior to extracorporeal liver support in the study group was $34(31-39)$ and $64 \%(n=25)$ of the patients were diagnosed with sepsis (SIRS + pocket of infection). In bacteriological analysis there were revealed Klebsiella pneumoniae, Staphylococcus haemolyticus, Acinetobacter baumannii, Pseudomonas aeruginosa, Enterococcus faecium in blood culture, and Klebsiella pneumoniae, Pseudomonas aeruginosa, Acinetobacter baumannii, and Stenotrophomonas maltophilia in bronchoalveolar lavage. At the moment of extracorporeal liver support procedures, MODS was verified in all patients.

At the beginning of extracorporeal liver support $82 \%$ $(n=32)$ of the patients also had acute kidney injury (failure or injury stage according to RIFLE) and received renal replacement therapy (daily online haemofiltration or haemodialysis).

Criteria to start Prometheus therapies were: serum bilirubin above $180 \mu \mathrm{mol} / \mathrm{l}$ (reference values 3-17 $\mu \mathrm{mol} / \mathrm{l}$ ), hepatocyte cytolysis syndrome (at least 2-fold increase in aspartate aminotranspherase (AST) and alanine aminotranspherase (ALT) concentrations; reference values 10-40 $\mathrm{U} / \mathrm{l}$ ) and decrease in plasma cholinesterase (reference values 4490-13320 U/l).

\section{Methodology of procedures}

Fractionated Plasma Separation and Adsorption was performed using the Prometheus system (Fresenius, Germany) and the appropriate therapeutic kit. There was 1 procedure (median) for each patient. The blood flow was 240-260 ml/min, while the plasma flow was $250-300 \mathrm{ml}$ min and bicarbonate dialysate flow was $500 \mathrm{ml} / \mathrm{min}$. The procedure duration was $6 \mathrm{~h}$.

Systemic anticoagulation was done with heparin; patients received an average dose of 14 (10-20) IU/ kg/h. ACT value was maintained at $180-220$ s. Patients were monitored for hemodynamics and blood gas content. Blood chemistry was evaluated before and immediately after the completion of extracorporeal therapy.

\section{Statistical analysis}

The statistical analysis was performed with Statistica 6.0 software. Considering the small sample size (39 patients), the median $\left(25^{\text {th }}, 75^{\text {th }}\right.$ percentile) was used to describe data. To quantitatively compare data within a group the Wilcoxon test was utilized. Differences were considered as significant at $p<0.05$.

\section{Results}

In the Prometheus therapy group there was statistically significant stabilization of hemodynamics: MAP increased by $13 \%(p<0.001)$, from $78(71-88) \mathrm{mm} \mathrm{Hg}$ initially to 90 (82-100) $\mathrm{mm} \mathrm{Hg}$ after the procedures. Cardiotonic support remained constant: adrenaline: $0.08(0.05-0.1) \mu \mathrm{g} / \mathrm{kg} / \mathrm{min}$,

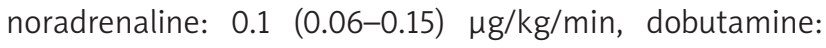
6 (4-8), dopamine: $5(3-7) \mu \mathrm{g} / \mathrm{kg} / \mathrm{min}$. It should be noted that there were only 8 patients with hyperthermia over $38^{\circ} \mathrm{C}$; everyone else had temperature not exceeding $37.5^{\circ} \mathrm{C}$. So stabilization of hemodynamics was not due to hyperthermia correction. Furthermore, after excluding all the patients with hyperthermia, stabilization of hemodynamics remained constant at $14 \%(p=0.027)$.

There were no negative changes in oxygenation lung function in this procedure. The oxygenation index prior to extracorporeal liver support was 2.25 (1.77-3) and did not change after therapy completion. The possibility to perform ultrafiltration within extracorporeal liver support procedures was one of the most important requirements to use these techniques in patients with cardio-respiratory dysfunction, which would prevent decompensation of the respiratory insufficiency, and in some cases increase the respiratory index.

According to our data, there were no significant negative dynamics of serous albumin concentration (it was 30 (27-35) prior to and 31 (28-35) g/l after the extracorporeal procedure $(p=0.43)$ (Tab. $I I))$, which was probably due to an adequate scheduled correction of hypoproteinemia and routine albumin transfusions for patients with ALF.

Despite the described losses of coagulation factors in the extracorporeal circuit during the Prometheus procedures [8], there were no clinically significant hemorrhagic complications related to extracorporeal procedures in our group.

The baseline total bilirubin level was 248 (164-355) $\mu \mathrm{mol} / \mathrm{l}$; unconjugated bilirubin concentration was 94 (68154) $\mu \mathrm{mol} / /$ (Tab. II). Extracorporeal liver support provided a statistically significant reduction in the total bilirubin concentration, by $15.5 \%(p<0.001)$. Prometheus therapy also provided unconjugated bilirubin clearance $(20 \%, p<0.001)$.

In our group serum aminotransferase levels, reflecting hepatocyte cytolysis syndrome, also had a positive dynamic: AST and ALT decreased by $14 \%(p=0.34)$ and $24 \%$ ( $p<0.001)$, respectively, being an indirect indicator of the reduction in liver parenchyma damage (Tab. II).

As the marker of liver synthesizing function we used serum cholinesterase, which has limited synthesis in hepatocytes and a short half-life (up to $2 \mathrm{~h}$ ). The increase in its concentration during extracorporeal liver support was $3 \%(p=0.33)$, which reflects the positive effect of this method on liver synthetic function. Baseline low level of anti-thrombin III (47\% (37-62) (Tab. II)) also indicated the reduction in the liver's synthetic function. There was a statistically non-significant increase of this parameter in the treated group (up to $51 \%$ (38-62), $p=0.06$ ).

Since the majority of patients received renal replacement therapy at enrollment, the baseline azotemia level was low: urea level was 15 (12-21) $\mathrm{mmol} / \mathrm{l}$, and creatinine level was $152(115-241) \mu \mathrm{mol} / \mathrm{l}$. In the course of extracorporeal liver support therapy there was a 33\% reduction in urea level $(p<0.001)$ and $21 \%$ reduction in creatinine ( $p<0.001$ ), which indicates high effectiveness of both methods in elimination of water-soluble toxic substances.

Renal replacement therapy performed in the majority of patients at enrollment reduced the informative value of serum ammonia level as a marker of hepatic encephalopa- 
Tab. II. Laboratory data at the beginning and immediately after the completion of extracorporeal liver support

\begin{tabular}{|c|c|c|c|}
\hline \multirow[t]{2}{*}{ Parameter } & \multicolumn{3}{|c|}{$\begin{array}{c}\text { Prometheus }(n=39) \\
\text { Median }(25-75) \\
p \text { (Wilcoxon test) }\end{array}$} \\
\hline & Before & After & $P$-value \\
\hline Total bilirubin $[\mu \mathrm{mol} / 1]$ & $248(164-355)$ & $185(124-275)$ & $<0.001$ \\
\hline Unconjugated bilirubin $[\mu \mathrm{mol} / \mathrm{l}]$ & $94(68-154)$ & $76(49-135)$ & $<0.001$ \\
\hline Aspartate aminotransferase [U/I] & $108(50-185)$ & $93(44-163)$ & 0.34 \\
\hline Alanine aminotransferase [U/I] & $58(33-103)$ & $44(28-73)$ & $<0.001$ \\
\hline Serum cholinesterase [U/I] & $2483(2085-3447)$ & 2557 (2087-3074) & 0.33 \\
\hline Creatinine $[\mu \mathrm{mol} / \mathrm{l}]$ & $152(115-241)$ & $120(89-174)$ & $<0.001$ \\
\hline Urea [mmol/l] & $15(12-21)$ & $10(6.8-14)$ & $<0.001$ \\
\hline Albumin $[\mathrm{g} / \mathrm{l}]$ & $30(27-35)$ & $31(28-35)$ & 0.43 \\
\hline INR & $1.53(1.23-1.78)$ & $1.52(1.22-1.98)$ & $<0.001$ \\
\hline Antithrombin III (\%) & $47(37-62)$ & $51(38-62)$ & 0.06 \\
\hline Venous blood lactate $[\mathrm{mmol} / \mathrm{l}]$ & $2.1(1.5-3.0)$ & $1.75(1.4-2.3)$ & 0.01 \\
\hline
\end{tabular}

INR - international normalized ratio

thy severity. There were no changes of this parameter in our group (baseline level was 48 (41-59) $\mathrm{mmol} / \mathrm{l}$, the level $12 \mathrm{~h}$ after the completion of a procedure was 48 (38-51) $\mathrm{mmol} / \mathrm{l} ; p=0.23$ ), probably due to the continuous increase in this metabolite in ALF.

One of the main efficacy criteria of an extracorporeal liver support therapy was its impact on the clinical outcome. In the course of combined intensive therapy, including the extracorporeal liver support, the 28-day survival rate was $23 \%(n=9)$. There was no correlation between clinical outcome and number of Prometheus procedures per patient. Lethal outcomes were related to MODS progression. Acute liver failure was a direct cause of lethal outcomes in none of the cases.

\section{Discussion}

The key aspect in evaluation of safety of Prometheus extracorporeal liver support therapy was the absence of complications and negative impact on hemodynamics and oxygenation lung function, as well as the severity of baseline dysproteinemia and coagulopathy.

In our group there were no cases of pyrogenic or allergic reactions, hemorrhagic complications or extracorporeal coagulation during the procedures. In our opinion, it is due to the "rebalanced" hemostatic status in acute liver failure. Despite profound hemostatic system abnormalities, the average patient with acute liver failure may be in hemostatic balance. In this case both pro- and antihemostatic factors are affected, and this is not well reflected in routine coagulation testing [9]. Furthermore, it has been well established that patients with acute liver failure have a normal thrombin generating capacity and a decreased capacity to remove fibrin clots. These results contrast with routine laboratory tests such as the PT/INR, which are by definition prolonged in patients with acute liver failure and suggest a bleeding tendency [10].

In our group there was also a statistically significant stabilization of hemodynamics and absence of negative changes in oxygenation lung function in this procedure. Our findings match the data obtained by other researchers, who noted that fractionated plasmatic separation and adsorption does not alter hemodynamic parameters in experimental acute liver failure study. They found no significant differences in mean arterial pressure, system vascular resistance or plasma lactate $(p>0.05)$ in the Prometheus-treated group and a significant decrease in HR at $3 \mathrm{~h}$, a significant increase in cardiac output at $9 \mathrm{~h}$ and a significant decrease in pulmonary artery wedge pressure at 6 and $12 \mathrm{~h}$ [11].

Another safety criterion for extracorporeal therapy was the absence of a reduction in serum albumin, which is very important in cases of baseline dysproteinemia in ALF and when using highly permeable hemo- or plasmafilters. According to many authors, the loss of albumin in the extracorporeal circuit during the Prometheus therapy may reach $2.9 \pm 0.9 \mathrm{~g} / \mathrm{l}(p=0.055)$ [12]. In our group there were no significant negative dynamics of serous albumin. Furthermore, Prometheus therapy can restore the albumin binding capacity [13].

When evaluating the effectiveness of investigating Prometheus therapy, we focused on dynamics of toxic hydrophobic and hydrophilic substance concentrations, as well as on the severity of hepatocyte cytolysis syndrome and liver synthetic function disorders.

Our findings match the data obtained by other researchers, who noted a reduction in the total bilirubin by 26-59\% when using Prometheus $[14,15]$ and only by $23 \%$ 
when using albumin dialysis [16]. The higher effectiveness of Prometheus therapy in unconjugated bilirubin and bile acids (45\%) [17] elimination was also shown before.

According to our foreign colleagues, the reduction in serum aminotransferase concentrations after Prometheus therapy may reach $56 \%$ for AST and $46 \%$ for ALT, but only in patients with toxic ALF etiology [18].

According to many authors, the impact of extracorporeal blood purification methods on survival rate in ALF was statistically insignificant $[19,20]$.

According to the prior research, the survival rate with Prometheus therapy varies from $41.6 \%$ to $44 \%$, achieving $66 \%$ when performing multiple procedures (8-11 procedures per patient) in patients without orthotopic liver transplant (OTLT) [21], and is $48-53.8 \%$ with treatment including OTLT [8]. The 1-year survival rate when using albumin dialysis was $21.3 \%$ in a group of patients not planning OTLT [16]. In one prospective study, the 6-month survival rate was $82.9 \%(p=0.5)$ in the course of MARS therapy compared to $75.5 \%$ in the group of conservative treatment. Such surprising results were due to OTLT performed in 66 out of 102 cases, as well as due to the short time interval from randomization to OTLT (on average 16.2 h) [21].

In a single-center, prospective randomized study, the survival rate in patients with hypoxic liver damage due to cardiogenic shock was $50 \%$ in the group of albumin dialysis, and $32 \%$ in the control group. It should be noted that one of the exclusion criteria in this study was sepsis (WBC greater than $12.5 \times 10^{9} /$, positive blood culture and hyperdynamic type of blood circulation at enrollment) [22].

The results of multi-center prospective randomized studies for this issue were also ambiguous. In the RELIEF study including 189 patients with exacerbation of chronic liver failure, the survival rate was $41.2 \%$ with MARS therapy compared to $40 \%$ in the conservative therapy group. However, when considering concomitant factors, the survival rate in the MARS therapy group reached 13\% [23]. In the HELIOS study including 145 patients with acute-on-chronic liver dysfunction receiving 8-10 Prometheus procedures, the increase in total survival rate was statistically insignificant. However, in the subgroup of patients with the most severe condition, i.e. with hepatorenal syndrome type I and MELD score above 30, a statistically significant increase in survival rate was found [24]. Taking such results into account, we recommend performing a differentiated evaluation of extracorporeal therapy effectiveness, including its effect on survival rate in specific patient subgroups.

\section{Conclusions}

Therefore, taking into account all benefits and drawbacks of the method, including effective reducing intracranial pressure [25], Prometheus procedures could be recommended as a part of combined intensive care in patients with acute liver failure after cardiac and vascular surgery. The efficiency of this method could be improved by a multifactor evaluation of patient condition in order to determine indications for its use.

\section{Disclosure}

Authors report no conflict of interest.

\section{References}

1. Babaev MA. Multiple organ failure syndrome after cardiovascular operations under artificial circulation. Ph.D Diss. Moscow 2011 (in Russian).

2. Daas M, Plevak DJ, Wijdicks EF, Rakela J, Wiesner RH, Piepgras DG, Dunn WF, Steers JL. Acute liver failure: results of a 5-year clinical protocol. Liver Transpl Surg 1995; 1: 210-219.

3. Gerth HU, Pohlen M, Pavenstädt H, Schmidt H. Extracorporeal liver support of liver failure. Z Gastroenterol 2017; 55: 383-393.

4. Saliba F, Samuel D. Artificial liver support: a real step forward. Minerva Med 2015; 106: 35-43.

5. Larsen FS, Schmidt LE, Bernsmeier C, Rasmussen A, Isoniemi H, Patel VC, Triantafyllou E, Bernal W, Auzinger G, Shawcross D, Eefsen M, Bjerring PN, Clemmesen JO, Hockerstedt K, Frederiksen HJ, Hansen BA, Antoniades CG, Wendon J. High-volume plasma exchange in patients with acute liver failure: an open randomised controlled trial. J Hepatol 2016; 64: 69-78.

6. Leckie P, Davenport A, Jalan R. Extracorporeal liver support. Blood Purif 2012; 34: 158-163.

7. Gong D, Ji D, Zhu D, Xu B, Liu Z. Efficient removal of serum bilirubin by a novel artificial liver support system using albumin convection: a pilot study (Китай). Blood Purif 2012; 34: 201-208.

8. Meijers BK, Verhamme P, Nevens F, Hoylaerts MF, Bammens B, Wilmer A, Arnout J, Vanrenterghem Y, Evenepoel P. Major coagulation disturbances during fractionated plasma separation and adsorption. Am J Transplant 2007; 7: 2195-2199.

9. Lisman T, Caldwell SH, Burroughs AK, Northup PG, Senzolo M, Stravitz RT, Tripodi A, Trotter JF, Valla DC, Porte RJ, Coagulation in Liver Disease Study Group Hemostasis and thrombosis in patients with liver disease. The ups and downs. J Hepatol 2010; 53: 362-371.

10. Lisman T, Bakhtiari K, Adelmeijer J, Meijers JCM, Porte RJ, Stravitz RT. Intact thrombin generation and decreased fibrinolytic capacity in patients with acute liver injury or acute liver failure. J Thromb Haemost 2012; 10: 1312-1319.

11. Laszikova E, Prazak J, Ryska O, Koblihova E, Tyll T, Ryska M. Fractionated plasmatic separation and adsorption does not alter haemodynamic parameters in experimental acute liver failure. Neuro Endocrinol Lett 2014; 35: 280-284.

12. Fuhrmann V, Horvatits T, Drolz A, Rutter K. Extracorporeal therapy of patients with liver disease in the intensive care unit. Med Klin Intensivmed Notfmed 2014; 109: 246-251.

13. Oettl K, Stadlbauer V, Krisper P, Stauber RE. Effect of extracorporeal liver support by molecular adsorbents recirculating system and Prometheus on redox state of albumin in acute-on-chronic liver failure. Ther Apher Dial 2009; 13: 431-436.

14. Nevens F, Laleman W. Artificial liver support devices as treatment option for liver failure. Best Pract Res Clin Gastroenterol 2012; 26: 17-26.

15. Gong D, Ji D, Zhu D, Xu B, Liu Z. Efficient removal of serum bilirubin by a novel artificial liver support system using albumin convection: a pilot study. Blood Purif 2012; 34: 201-208.

16. Donati G, La Manna G, Cianciolo G, Grandinetti V, Carretta E, Cappuccilli M, Panicali L, Iorio M, Piscaglia F, Bolondi L, Colì L, Stefoni S. Extracorporeal detoxification for hepatic failure using molecular adsorbent recirculating system: depurative efficiency and clinical results in a long-term follow-up. Artif Organs 2014; 38: 125-134.

17. Stadlbauer V, Krisper P, Beuers U, Haditsch B, Schneditz D, Jung A, PutzBankuti C, Holzer H, Trauner M, Stauber RE. Removal of bile acids by two different extracorporeal liver support systems in acute-on-chronic liver failure. ASAIO I 2007; 53: 187-193.

18. Grodzicki M, Kotulski M, Leonowicz D, Zieniewicz K, Krawczyk M. Results of treatment of acute liver failure patients with use of the prometheus FPSA system. Transplant Proc 2009; 41: 3079-3081.

19. Lee K, Mun CH, Min BG. Development of a multifunctional detoxifying unit for liver failure patients. Blood Purif 2012; 34: 225-230.

20. Kribben A, Gerken G, Haag S, Herget-Rosenthal S, Treichel U, Betz C, Sarrazin C, Hoste E, Van Vlierberghe H, Escorsell A, Hafer C, Schreiner O, Galle PR, Mancini E, Caraceni P, Karvellas CJ, Salmhofer H, Knotek M, Ginès P, KozikJaromin J, Rifai K; HELIOS Study Group. Effects of fractionated plasma separation and adsorption on survival in patients with acute-on-chronic liver failure. Gastroenterology 2012; 142: 782-789. 
21. Saliba F, Camus C, Durand F, Mathurin P, Letierce A, Delafosse B, Barange K, Perrigault PF, Belnard M, Ichaï P, Samuel D. Albumin dialysis with a noncell artificial liver support device in patients with acute liver failure: a randomized, controlled trial. Ann Intern Med 2013; 159: 522-531.

22. El Banayosy A, Kizner L, Schueler V, Bergmeier S, Cobaugh D, Koerfer R. First use of the Molecular Adsorbent Recirculating System technique on patients with hypoxic liver failure after cardiogenic shock. ASAIO I 2004; 50: 332-337.

23. Bańares R, Nevens F, Larsen FS, Jalan R, Albillos A, Dollinger M. Extracorporeal liver support with the molecular adsorbent recirculating system (MARS) in patients with acute-on-chronic liver failure (AOCLF). The RELIEF trial. J Hepatol 2010; 52: S459-S460.
24. Rifai K, Kribben A, Gerken G, Haag S, Herget-Rosenthal S, Treichel U, Betz C, Sarrazin C, Van Vlierberghe H, Hoste E, Escorsell A, Gines P, Hafer C, Schuchmann M, Galle PR, Bernardi M, Caraceni P, Abeles D, Berr F, Knotek M, Kozik-Jaromin J; the HELIOS Study Group. Extracorporeal liver support by Fractionated Plasma Separation and Adsorption (Prometheus) in patients with acute-on-chronic liver failure (HELIOS study): a prospective randomized controlled multicenter study. J Hepatol 2010; 52: S3.

25. Ryska O, Pantoflicek T, Laszikova E, Prazak J, Koblihova E, Ryska M. Artificial liver support system reduces intracranial pressure more effectively than bioartificial system: an experimental study. Int J Artif Organs 2012; 35: 503-510. 